\title{
Głos w dyskusji na temat stosowania Journal Impact Factor do oceny wyników badań naukowych, indywidualnych naukowców i ośrodków badawczych
}

\author{
Beata Sas-Korczyńska
}

Invited commentary

„Wartość dzieł człowieka nie kryje się zgoła w nich samych, ale w rozwoju, jaki przydaja im dzieła inne i okoliczności późniejsze" Paul Ambroise Valéry (1871-1945)

W ocenie badaczy - autorów pracy uwzględniana jest rzeczywista wartość naukowa publikacji, o której decyduje liczba jej cytowań przez innych autorów. Stosowanie do oceny autorów - badaczy Journal Impact Factor (JIF) czasopisma, w którym opublikowana została ich praca, nie wskazuje na rzeczywistą wartość pracy i jej autora(-ów), bowiem opublikowanie pracy w czasopiśmie o wysokiej wartości JIF nie jest jednoznaczne z tym, że jest/będzie ona często cytowana. Ponadto może zdarzyć się, iż praca opublikowana w czasopiśmie o niskiej wartości wskaźnika oddziaływania może mieć wysoki wskaźnik cytowań. Zatem nie można mówić o prostym przełożeniu wartości JIF czasopisma na wartość publikowanych w nim wyników badań i poprzez to oceniać autorów i instytucje, w których pracują. Poza tym część prac może być cytowana po okresie dwóch lat, czyli takim, który uwzględniany jest w określaniu wartości JIF, a w rzetelnej ocenie autora istotne jest całkowite oddziaływanie jego publikacji, a więc wskaźnik cytowań w ogóle, a nie tylko w określonym czasie.

Czynniki te wskazują, że JIF nie jest właściwym parametrem służącym do oceny rzeczywistej wartości publikowanych prac (a przez to i ich autorów). Ponadto wskaźnik ten nie jest w pełni obiektywnym czynnikiem oceny czasopism. JIF z definicji jest miarą oddziaływania i prestiżu czasopism naukowych, o jego wartości decyduje wskaźnik cytowań publikacji, które ukazały się w czasopismach wskazanych przez Instytut Filadelfijski. Jest to przyczyna krytyki i licz- nych kontrowersji, ponieważ wybór czasopism odbywa się na podstawie prawa Bradforda (według którego w każdej dziedzinie naukowej $99 \%$ istotnych publikacji ukazuje się w niewielkiej liczbie czasopism). Powoduje to, iż około 95\% czasopism jest tutaj pominiętych jako czasopisma mniej znane lub wydawane w innych językach niż język angielski (ponad 80\% to czasopisma anglojęzyczne). Ponadto ponad 50\% czasopism znajdujących się na liście to czasopisma wydawane w USA. Kolejne kontrowersje dotyczą selekcji tematyki publikacji („podążanie za modą”, czyli preferowanie badań o modnej tematyce) oraz okresu cytowań (dwa lata od ukazania się publikacji). Publikowanie prac o niepopularnej lub dotyczącej nowych zagadnień tematyce związane jest z ryzykiem utraty wartości JIF poprzez zmniejszenie zainteresowania czasopismem i ryzyko braku cytowań w okresie wyznaczonym przez definicję. Z drugiej strony może zdarzyć się, że artykuł, który jest "niemodny” w czasie dwóch lat po publikacji, po tym okresie może być masowo cytowany, ale tego JIF już nie obejmuje.

Wyznaczanie wartości JIF powstało w celu oceny czasopism, jednak obecnie służy również do oceny autorów publikacji i instytucji naukowych, z których oni pochodzą. Takie postępowanie budzi wątpliwości [1-5] i pojawia się pytanie, czy w tym przypadku rzeczywiście, „liczbajest istota wszystkich rzeczy" (Pitagoras). Inaczej mówiąc, czy wartość JIF czasopisma oddaje rzeczywistą wartość naukową publikacji i ich autorów? Według autora tego „głosu w dyskusji” 
— nie. Autor zgadza się ze stanowiskiem Redaktora Naczelnego niniejszego pisma przedstawionym w publikacji.

\section{Prof. nadzw. dr hab. med. Beata Sas-Korczyńska}

Klinika Onkologii

Centrum Onkologii — Instytut im. Marii Skłodowskiej-Curie, Oddział w Krakowie

ul. Garncarska 11, 31-115 Kraków

e-mail:z5korczy@cyf-kr.edu.pl

\section{Piśmiennictwo}

1. Jadacki J. Czy Kopernik zasługiwałby na tytuł profesora? O tym, jak oceniać naukowców? Nowotwory J Oncol 2012; 62: 134-138.

2. Oświadczenie Europejskiego Stowarzyszenia Redaktorów Naukowych (European Association of Science Editors - EASE) w sprawie niewłaściwego stosowania wskaźników oddziaływania (IF — impact factors). Nowotwory J Oncol 2012; 62: 139-140.

3. Deklaracja z San Francisco nt. Oceny Badań Naukowych (DORA): czy to początek końca dotychczasowej metody oceny prametrycznej? Nowotwory J Oncol 2013; 63: 501-504.

4. Wróblewski AK. Czas wrócić do rozsądku. Nowotwory J Oncol 2013; 63: 66-67.

5. Brzeziński JM. O konieczności utrzymania habilitacji w Polsce. Nowotwory J Oncol 2015; 65: 292-297. 